\title{
PENGEMBANGAN PROGRAM BERITA INFOTAINMENT TV NASIONAL BERDASARKAN PREFERENSI MASYARAKAT MENGGUNAKAN ANALISIS KONJOIN
}

\author{
Putri Dameyanti $^{1 \S}$, Made Susilawati ${ }^{2}$, Desak Putu Eka Nilakusmawati ${ }^{3}$
}

\begin{abstract}
${ }^{1}$ Program Studi Matematika, Fakultas MIPA - Universitas Udayana [Email: pdameyanti@ gmail.com]
${ }^{2}$ Program Studi Matematika, Fakultas MIPA - Universitas Udayana [Email: mdsusilawati@unud.ac.id]

${ }^{3}$ Program Studi Matematika, Fakultas MIPA - Universitas Udayana [Email:nilakusmawati@unud.ac.id]

${ }^{\S}$ Corresponding Author
\end{abstract}

\begin{abstract}
Current technological advances cause information to be obtained quickly. Such information can be obtained through printed media or electronic media. Television is included in the category of electronic media. The infotainment program is one of the television programs. Almost all television stations have infotainment programs running every day. This proves that people love the infotainment program, so the infotainment program still running until now. People's as watchers/audiens of the infotainment program have the right to provide an assessment of the quality of infotainment programs related to satisfaction and preference to assist in the development of infotainment programs. To understand people's preferences for infotainment programs, it can be done using conjoint analysis. In this research, it was found that the attributes that influence the people's in watching infotainment program are presenter, air time, and program duration. In general, the infotainment program that desired by the people was an infotainment program that has a paired presenter, running at night with a half hour run time
\end{abstract}

Keywords : Conjoint Analysis (CA), Infotainment Program, Preference.

\section{PENDAHULUAN}

Kemajuan teknologi saat ini membuat informasi dapat diperoleh dengan cepat. Informasi tersebut diperoleh melalui media cetak atau media elektronik. Menurut Santosa (2011) menyelisik lika-liku infotainment di media televisi "televisi sekarang ini bukan hanya sebagai alat untuk mendapatkan informasi, tetapi juga untuk hiburan”. Banyak orang terhibur dengan program-program televisi yang disediakan oleh siaran televisi baik siaran televisi swasta atau siaran televisi milik pemerintah. Akhir-akhir ini muncul beberapa program televisi yang baru dan selalu berusaha menarik perhatian masyarakat untuk menonton program tersebut, dengan harapan akan menaikkan rating stasiun televisi yang menayangkan program itu.

Infotainment merupakan salah satu program stasiun televisi. Pada penelitian Hasmira (2012) tentang "Analisis Dampak Sosial Pendidikan Tayangan Infotainment TV Swasta di Indonesia". Berita perbuatan asusila dan pemakaian narkoba pun dianggap sah-sah saja untuk ditayangkan pada infotainment. Tanpa disadari banyak para remaja yang juga menonton berita infotainment di televise dan dikhawatirkan para remaja ini akan melakukan hal yang sama

Masyarakat sebagai pemirsa atau pihak yang berkepentingan terhadap televisi, layak untuk memberikan evaluasi atau penilaian terhadap kualitas program televisi maupun kualitas stasiun televisi yang berkaitan dengan kepuasan dan preferensi untuk membantu pengembangan program televisi. Untuk mengungkapkan nilai-nilai konsumen berita infotainment maupun masyarakat dan memahami preferensi konsumen terhadap suatu produk, ide, dan jasa dapat dilakukan menggunakan analisis konjoin. Analisis 
konjoin mdalah salah satu teknik analisis multivariat yang dikembangkan secara khusus untuk memahami preferensi konsumen terhadap suatu objek (ide, jasa, produk).

Tujuan dari penelitian ini adalah untuk mengetahui preferensi masyarakat terhadap program-program berita infotainment dengan menggunakan analisis konjoin.

Analisis konjoin mulai diperkenalkan pada pertengahan tahun 1970. Manfaat analisis konjoin bagi produsen adalah untuk mencari solusi yang optimal dalam merancang suatu produk baru.

Dalam pemasaran analisis konjoin biasanya digunakan untuk hal-hal berikut ini:

1. Menentukan tingkat kepentingan relatif atibut-atribut pada proses pemilihan yang dilakukan oleh konsumen

2. Menentukan komposisi produk yang paling disukai oleh konsumen

3. Membuat estimasi pangsa pasar suatu produk tertentu yang berbeda tingkat atributnya

4. Membuat segmentasi pasar yang didasarkan pada kemiripan preferensi terhadap tingkattingkat atribut.

Menurut Green dan Krieger (1991) dalam Mattjik \& Sumertajaya (2011) analisis ini dapat juga dimanfaatkan untuk:

1. Merancang harga

2. Memprediksi tingkat penjualan dan penggunaan produk (market share), uji coba konsep produk baru

3. Segmentasi preferensi

4. Merancang strategi promosi

Tahapan pada umumnya yang dilakukan dalam merancang dan melakukan analisis konjoin adalah

1. Merumuskan masalah

2. Merancang stimuli (kombinasi atribut dengan level atribut)

3. Penentuan jenis data yang diperlukan

4. Menentukan metode analisis

5. Hasil analisis dan interpretasinya Secara umum model dasar analisis konjoin dapat dituliskan sebagai berikut:

dengan:

$$
U(X)=\sum_{i=1}^{m} \sum_{j=1}^{k_{1}} \beta_{i j} x_{i j}
$$

$$
\begin{aligned}
U(X)= & \text { Utility total } \\
\beta_{i j}= & \text { Part } \text { worth atau nilai } \\
& \text { kegunaan dari atribut ke-i } \\
& \text { level ke-j } \\
k_{i}= & \text { Level ke-j dari atribut ke-i }
\end{aligned}
$$

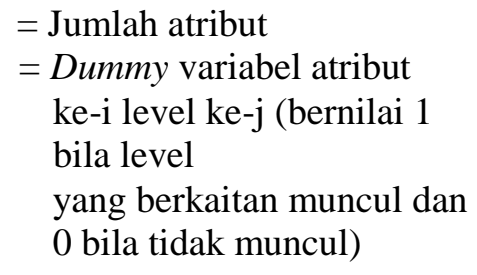

Preferensi dikembangkan berdasarkan penilaian kombinasi atribut terhadap suatu objek. Kombinasi yang terbentuk tergantung dari jumlah atribut dan jumlah level dari atribut objek tersebut. Sebagai contoh jika terdapat empat atribut dengan dua level, maka kombinasi yang terbentuk adalah $(2 * 2 * 2 * 2)$ yaitu enam belas kombinasi. Dari kombinasi inilah kemudian dapat dipahami preferensi konsumen.

\section{METODE PENELITIAN}

Tempat dilakukannya penelitian ini adalah Kota Denpasar karena keadaannya yang heterogen dan cukup mewakili daerah lainnya Waktu penelitian dilakukan Agustus 2016. Data yang digunakan adalah data primer yang diperoleh melalui kuisioner kepada 100 orang responden. Objek observasi dari penelitian ini adalah masyarakat disekitar kota Denpasar berusia 17 sampai 45 tahun yang menggemari program berita infotainment. Penarikan sampel pada penelitian ini menggunakan metode purposive sampling, yaitu penarikan sampel dengan adanya syarat tertentu pada responden.

Dalam penelitian ini dilakukan dua kali penyebaran kuisioner. Kuisioner pertama yaitu penelitian pendahuluan yang diberikan kepada 30 orang responden untuk mendapatkan tiga atribut utama dari enam atribut yang ada agar memudahkan responden dalam memberikan penilaian terhadap kombinasi atribut dan level. Kuisioner kedua berupa kartu stimuli yang berisi kombinasi antara 3 atribut utama dan disebarkan kepada 100 orang responden. Setiap responden diminta untuk memberikan nilai pada setiap profil atau kombinasi yang ada sesuai keinginan mereka

Atribut dalam penelitian ini yaitu:

a. Presenter yang terdiri dari dua level yaitu level pertama presenter solo dan level kedua presenter berpasangan.

b. Style yang terdiri dari dua level yaitu level pertama resmi dan level kedua casual.

c. Set yang terdiri dari dua level yaitu level pertama permainan grafis/desain dan level kedua penambahan perangkat pendukung.

d. Kedalaman berita terdiri dari dua level yaitu level pertama ringan dan unik, level 
kedua analisa mendalam

e. Waktu tayang terdiri atas tiga level yaitu level pertama pagi hari, level kedua siang hari, dan level ketiga malam hari.

f. Lama tayang terdiri atas dua level yaitu level pertama satu jam dan level kedua setengah jam.

Selanjutnya langkah-langkah yang dilakukan dalam penelitian ini yaitu sebagai berikut: (a) Menentukan atribut program infotainment dan level dari atribut tersebut; (b) Mendesain stimuli; (c) Memilih metode konjoin; (d) Pengumpulan data; (e) Melakukan uji validitas dan reliabilitas terhadap kuisioner yang dibuat; (f) Analisis konjoin; g) Interpretasi hasil.

\section{HASIL DAN PEMBAHASAN}

Pembagian kuisioner pertama disebar kepada 30 orang responden untuk mendapatkan 3 atribut utama yang menjadi preferensi masyarakat dalam menonton program infotaiment. Dari kuisioner tersebut diperoleh tiga atribut utama yaitu presenter atau pembawa acara, waktu tayang, dan lama tayang. Berikut hasil ranking yang diberikan oleh responden untuk masing-masing atribut.

Tabel 1 Total Ranking yang Diberikan Responden

\begin{tabular}{|c|c|c|}
\hline No & Atribut & Total Ranking \\
\hline 1 & Presenter & 66 \\
\hline 2 & Style & 95 \\
\hline 3 & Set Studio & 177 \\
\hline 4 & Kedalaman Berita & 123 \\
\hline 5 & Waktu Tayang & 80 \\
\hline 6 & Lama Tayang & 89 \\
\hline
\end{tabular}

Sumber : Data diolah, 2017

Berdasarkan pembagian kuisioner yang sebelumnya diperoleh 12 stimuli (profil) tetapi mengingat 12 kombinasi kemungkinan akan membuat responden merasa sulit untuk menilai kuisioner, sehingga dilakukan orthogonal array, yaitu kelas desain factorial yang memungkinkan untuk membuat perkiraan yang efisien dari seluruh pengaruh utama, sehingga diperoleh delapan kombinasi/card yang akan dinilai oleh responden.

Data yang telah diperoleh melalui penyebaran kuisioner selanjutnya diuji validitas dan reliabilitasnya terlebih dahulu. Pertanyaan dalam kuisioner dikatakan valid jika koefisien korelasi antar item pertanyaan mempunyai skor total lebih besar dari 0,30. Pertanyaan dalam kuisioner dikatakan reliabel (dapat dipercaya) jika nilai Cronbach's alpha lebih besar dari 0,60 (Ghozali, 2011).

Tabel 2. Kombinasi Atribut dengan Level (Profil) Program Infotainment

\begin{tabular}{|c|c|c|c|}
\hline Profil & Presenter & $\begin{array}{c}\text { Waktu } \\
\text { Tayang }\end{array}$ & Lama Tayang \\
\hline 1 & Solo & Pagi Hari & Satu Jam \\
\hline 2 & Berpasangan & Pagi Hari & Setengah Jam \\
\hline 3 & Solo & Siang Hari & Satu Jam \\
\hline 4 & Berpasangan & $\begin{array}{c}\text { Malam } \\
\text { Hari }\end{array}$ & Satu Jam \\
\hline 5 & Solo & $\begin{array}{c}\text { Malam } \\
\text { Hari }\end{array}$ & Setengah Jam \\
\hline 6 & Berpasangan & Siang Hari & Setengah Jam \\
\hline 7 & Solo & Pagi Hari & Setengah Jam \\
\hline 8 & Berpasangan & Pagi Hari & Satu Jam \\
\hline
\end{tabular}

Sumber: Data diperoleh dari proses SPSS 24

Tabel 3. Nilai Korelasi Antaritem-Total Skor dan Nilai Cronbach's Alpha

\begin{tabular}{|c|c|c|}
\hline Atribut & $\begin{array}{c}\text { Corrected Item- } \\
\text { Total Correlation }\end{array}$ & Keterangan \\
\hline Profil 1 & 0,686 & Valid \\
\hline Profil 2 & 0,668 & Valid \\
\hline Profil 3 & 0,392 & Valid \\
\hline Profil 4 & 0,510 & Valid \\
\hline Profil 5 & 0,451 & Valid \\
\hline Profil 6 & 0,431 & Valid \\
\hline Profil 7 & 0,601 & Valid \\
\hline Profil 8 & 0,525 & Valid \\
\hline \multicolumn{2}{|c|}{ Cronbach's Alpha } & 0,651 \\
\hline
\end{tabular}

Sumber : Hasil olah data dengan software SPSS 24

Berdasarkan tabel 3 memperlihatkan bahwa korelasi antara masing-masing profil (profil 1 sampai profil 8) terhadap total skor menunjukan hasil yang signifikan. Pertanyaan dalam kuisioner dikatakan valid jika koefisien korelasi antaritem pertanyaan mempunyai skor total lebih besar dari nilai $r_{\text {tabel }}$. Pada kasus ini responden sebanyak 30 orang dan nilai $r_{\text {tabel }}$ $(30 ; 28)$ adalah 0,30 . Semua nilai tersebut menunjukkan bahwa profil 1 sampai profil 8 valid, karena nilai korelasinya lebih besar dari 0,30. Nilai Cronbach's Alpha sebesar 0,651 > 
0,60 menyatakan bahwa instrumen pengukuran yang digunakan untuk semua profil dapat dipercaya.

Karateristik responden dalam penelitian ini meliputi jenis kelamin, dan usia. Dari penyebaran kuisioner diperoleh karateristik responden sebagai berikut:

Tabel 4. Karateristik Responden Menurut Jenis Kelamin dan Usia

\begin{tabular}{|c|c|c|c|c|}
\hline \multirow[t]{2}{*}{ No } & \multirow[t]{2}{*}{ Usia } & \multicolumn{2}{|c|}{$\begin{array}{c}\text { Jenis } \\
\text { Kelamin }\end{array}$} & \multirow[t]{2}{*}{ Total } \\
\hline & & $\mathrm{Lk}$ & $\mathrm{Pr}$ & \\
\hline 1 & $17-23$ tahun & 6 & 19 & 25 \\
\hline 2 & $24-30$ tahun & 5 & 16 & 21 \\
\hline 3 & $31-37$ tahun & 1 & 22 & 23 \\
\hline 4 & $38-45$ tahun & 0 & 31 & 31 \\
\hline & Total & 14 & 86 & 100 \\
\hline
\end{tabular}

Sumber : Data diolah, 2017

Dapat dilihat pada Tabel 4 persentase penggemar program berita infotainment paling banyak adalah pemirsa program infotaiment berjenis kelamin perempuan. Secara umum masyarakat yang menonton program infotainment lebih banyak perempuan.

Pada tabel 4 dengan jumlah responden 100 orang terlihat bahwa penggemar program infotainment paling banyak adalah responden yang berusia 38 tahun -45 tahun sebanyak 31 orang, kemudian responden yang berusia 17 tahun- 23 tahun sebanyak 25 orang, selanjutnya responden yang berusia 31 tahun -37 tahun sebanyak 23 orang, dan terakhir responden yang berusia 24 tahun - 30 tahun sebanyak 21 orang. Dari Tabel 4 dapat dilihat bahawa masyarakat yang menonton program infotainment lebih banyak berusia 38 tahun sampai 45 tahun.

Analisis konjoin dilakukan untuk mengetahui persepsi seseorang terhadap suatu objek. Hasil utama analisis konjoin adalah suatu bentuk (desain) produk, barang, atau jasa yang diinginkan oleh sebagian besar responden.

Hasil analisis konjoin pada tabel 5 terlihat atribut presenter, waktu tayang dan, lama tayang memengaruhi masyarakat dalam menonton infotainment dengan nilai signifikansi $p$ dibawah 0,05 . Atribut yang dianggap paling penting oleh masyarakat dalam menonton program infotainment adalah atribut waktu tayang dengan nilai kepentingan relatif sebesar 55,47\%. Fungsi utilitas (part worth) untuk waktu tayang pada malam hari 0,773. Waktu malam hari merupakan waktu tayang yang memiliki utilitas paling tinggi dibandingkan waktu lainnya yaitu $-0,295$ untuk pagi hari dan 0,478 untuk siang hari. Hal ini menunjukkan bahwa masyarakat lebih menyukai menonton program infotainment pada malam hari.

Tabel 5. Tingkat Relatif dan Nilai Utilitas Taraf Atribut Program Infotainment Masyarakat Denpasar

\begin{tabular}{|c|c|c|c|}
\hline $\begin{array}{l}\text { Nama } \\
\text { Atribut }\end{array}$ & $\begin{array}{l}\text { Tingkat } \\
\text { Atribut }\end{array}$ & $\begin{array}{c}\text { Bobot } \\
\text { Kepenting- } \\
\text { an Relatif } \\
(\%)\end{array}$ & Utilitas \\
\hline \multirow{2}{*}{ Presenter } & Solo & \multirow{2}{*}{$22,70 \%$} & $-0,301$ \\
\hline & Berpasangan & & 0,301 \\
\hline \multirow{3}{*}{$\begin{array}{l}\text { Waktu } \\
\text { Tayang }\end{array}$} & Pagi Hari & \multirow{3}{*}{$55,47 \%$} & $-0,295$ \\
\hline & Siang Hari & & $-0,478$ \\
\hline & Malam Hari & & 0,773 \\
\hline \multirow{2}{*}{$\begin{array}{c}\text { Lama } \\
\text { Tayang }\end{array}$} & Satu Jam & \multirow{2}{*}{$21,82 \%$} & $-0,284$ \\
\hline & $\begin{array}{l}\text { Setengah } \\
\text { Jam }\end{array}$ & & 0,284 \\
\hline \multicolumn{4}{|l|}{ Catatan: } \\
\hline
\end{tabular}

Sumber: Data diperoleh dari proses SPSS 24

Atribut yang memiliki nilai kepentingan relatif terbesar kedua adalah atribut presenter yaitu sebesar 22,70\%. Presenter berpasangan memiliki nilai utilitas lebih besar yaitu 0,301 daripada nilai utilitas presenter solo yaitu 0,301 . Hal ini menunjukkan bahwa masyarakat yang menjadi responden pada penelitian ini lebih menyukai menonton program infotainment dengan pembawa acara yang berpasangan, dikarenakan masyarakat merasa bosan untuk menonoton infotainment jika presenternya hanya satu orang.

Atribut yang memiliki nilai kepentingan terkecil adalah atribut lama tayang sebesar $21,82 \%$. Pada atribut ini level setengah jam $(0,284)$ mempunyai nilai utilitas lebih tinggi daripada level satu jam $(-0,284)$. Oleh karena itu, masyarakat kota Denpasar lebih menyukai menonton program infotainment selama setengah jam dibanding dengan satu jam. Hal ini dikarenakan masyarakat merasa terlalu lama untuk menonton program infotaimen selama satu jam.

Jika utilitas bernilai positif, maka responden menyukai level atribut tersebut, begitu juga sebaliknya jika utilitas bernilai negatif maka responden tidak menyukai level atribut tersebut. 
Hal ini disebabkan karena semakin besar nilai yang diberikan responden atau semakin besar minat responden terhadap suatu level dari atribut maka semakin besar nilai utilitasnya begitu juga sebaliknya. Pada penelitian ini angka 1 menyatakan level atribut yang tidak disukai responden, dan angka 10 menyatakan level atribut yang paling disukai responden.

Tingginya preferensi masyarakat terhadap atribut waktu tayang menunjukkan bahwa pada umumnya responden akan mempertimbangkan waktu yang tepat untuk menonton infotainment.

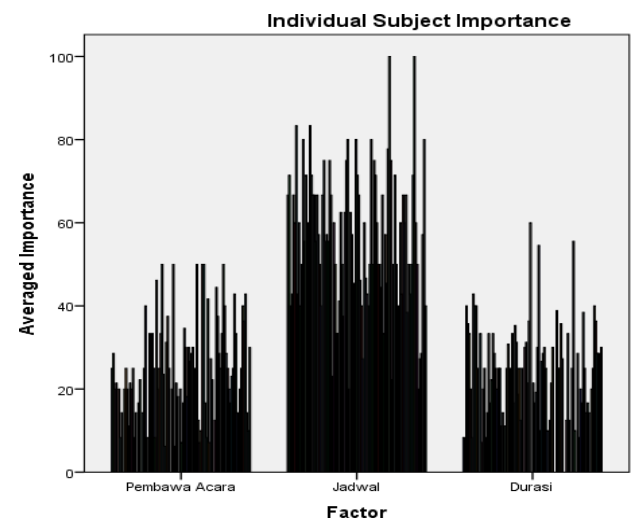

Gambar 1 Tingkat Kepentingan Relatif Atribut

Gambar 1 adalah gambar yang menunjukkan tingkat kepentingan relatif oleh responden terhadap ketiga atribut. Dari Gambar 1 terlihat bahwa nilai atribut waktu tayang memiliki nilai paling tinggi. Artinya responden lebih dominan mempertimbangkan waktu tayang dalam menonton infotainment dibandingkan dengan atribut pembawa acara dan atribut lama tayang. Atribut presenter dan lama tayang mempunyai nilai yang hampir sama, artinya 100 responden tidak terlalu dominan mempertimbangkan kedua atribut tersebut dalam menonton infotainment.

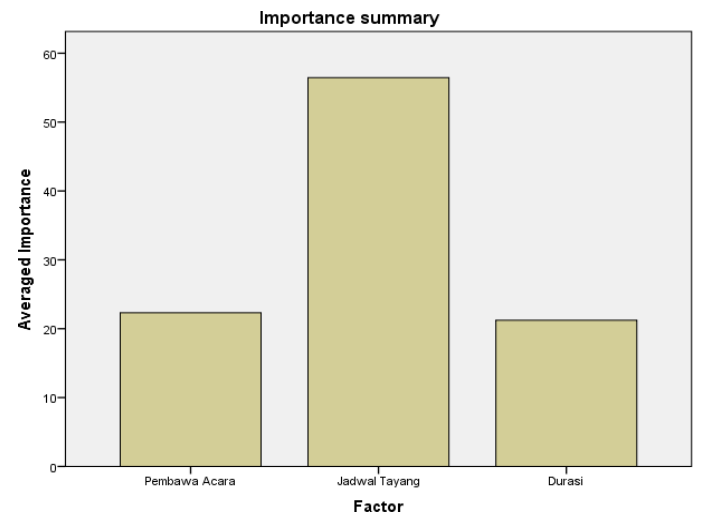

Gambar 2 Hasil Preferensi Responden
Dari Gambar 2 menampilkan factor (atribut), averaged important (rata-rata kepentingan relatif), dan importance summary (tingkatan kepentingan relatif) terlihat bahwa dari atribut jadwal tayang memiliki nilai tertinggi dibandingkan dengan atribut presenter dan atribut lama tayang. Hal ini berarti bahwa faktor jadwal tayang merupakan faktor utama yang menjadi pertimbangan responden untuk menonoton program infotainment. Hal tersebut dapat terjadi karena sebagian besar atau dominan yang menjadi responden adalah ibu rumah tangga dan wanita yang bekerja, yang tentunya akan lebih memilih menonton di malam hari ketika mereka tidak mempunyai pekerjaan lagi.

\section{KESIMPULAN DAN SARAN}

\subsection{Kesimpulan}

Berdasarkan hasil dan pembahasan pada penelitian ini dapat diberikan simpulan berikut: Hasil analisis secara agregat menunjukkan bahwa atribut presenter, waktu tayang, dan lama tayang merupakan atribut yang memengaruhi masyarakat terhadap menonton program infotainment. Dengan orthogonal array diperoleh 8 stimuli yang dalam penelitian ini dinamakan 8 profil yang dinilai oleh responden untuk mengetahui preferensi masyarakat terhadap program infotainment.

Hasil analisis konjoin menunjukkan dari nilai utilitasnya masyarakat lebih menyukai program infotainment yang mempunyai presenter berpasangan daripada presenter solo. Masyarakat lebih dominan untuk menonton program infotainment pada malam hari daripada pagi hari ataupun siang hari. Dari segi lama tayang masyarakat lebih menyukai infotainment yang tayangnya setengah jam daripada infotainment yang tayang selama satu jam. Sehingga secara umum program infotainment yang diinginkan oleh masyarakat dalam penelitian ini adalah program infotainment yang mempunyai presenter berpasangan, tayang pada malam hari dengan lama tayang setengah jam.

Untuk penelitian selanjutnya dapat dilakukan penelitian mengenai program televisi lainnya, atau dapat dilakukan penelitian terhadap bidang yang lain. 


\section{DAFTAR PUSTAKA}

Ghozali, Imam. 2011. Aplikasi Analisis Multivariate Dengan Program IBM SPSS 19 Edisi 5. Semarang: Badan Penerbit Universitas Diponegoro.

Hasmira M.H. Oktober 2012.

"Analisis Dampak Sosial Pendidikan Tayangan Infotainment TV Swasta di Indonesia". Jurnal-jurnal ilmu-ilmu sosial budaya dan ekonomi. Vol. 8, No. 2, hal. 194. http://ejournal.unp.ac.id/index.php/ting kap/article/view/1883.html. Diakses tanggal 01 Oktober 2015

Mattjik, Ahmad Ansori \& Sumertajaya I Made. 2011. Sidik Peubah Ganda dengan Menggunakan SAS. Bogor: Departemen Statistika, Ilmu Pertanian Bogor

Santosa, Pudjo Hedi .2011. Menelisik Lika Liku Infotainment di Media Televisi. Gapai Asa Media Prima. Fakultas Ilmu Sosial dan Politik, Jurusan Ilmu Komunikasi. http://eprints.undip.ac.id/34077/. Diakses tanggal 02 Oktober 2015 